\title{
Sorbitol-Plasticized and Neutralized Chitosan Membranes as Skin Substitutes
}

\author{
Maria Gabriela Nogueira Campos ${ }^{*}$, Lucia Helena Innocentini Meib, Arnaldo Rodrigues Santos Jrc
}

\author{
${ }^{a}$ Instituto de Ciência e Tecnologia, Universidade Federal de Alfenas - UNIFAL, \\ Poços de Caldas, $M G$, Brazil \\ ${ }^{b}$ Faculdade de Engenharia Quimica, Universidade de Campinas - UNICAMP, Campinas, SP, Brazil \\ ${ }^{c}$ Centro de Ciencias Naturais e Humanas, Universidade Federal do ABC-UFABC,
}

Santo André, SP, Brazil

Received: May 5, 2015; Revised: June 29, 2015

\begin{abstract}
Chitosan is soluble in diluted acid solutions and can easily form films by casting. However, residual acid neutralization should be performed for biomedical applications what may compromise physical and mechanical properties of the films. Thus, plasticizers can be added to improve these properties. The aim of this study was to characterize morphological, barrier and mechanical properties, besides evaluate the in vitro cytotoxicity of sorbitol-plasticized and $\mathrm{NaOH}-\mathrm{Na}_{2} \mathrm{CO}_{3}$ neutralized chitosan membranes for skin substitute application. Scanning electron microscopy, X-ray diffraction, water vapor permeability and mechanical tests were carried out to characterize the obtained membranes. Moreover, Vero cells were used for in vitro cytotoxicity evaluation. In this paper, we report a non-cytotoxic sorbitol-plasticized chitosan membrane with desirable properties for skin substitution, such as flexibility, water vapor permeability and high percentage of elongation.
\end{abstract}

Keywords: chitosan, sorbitol, skin substitute, cytotoxicity, Vero cells

\section{Introduction}

The loss or failure of an organ or tissue is one of the most frequent, devastating, and costly problems in human health care. Tissue engineering, is a new research field that applies the principles of biology and engineering to the development of functional substitutes for damaged tissue. Overall, tissue engineering appears to be the new frontier of medicine dedicated to regenerative and reconstructive procedures in humans by developing powerful new therapies to treat structural and functional disorders impossible to treat successfully with the current approaches of interventional medicine ${ }^{1}$.

Several commercial products were developed during the last 30 years. Most of them were designed for permanent use, some of them as temporary substitutes. They contain cells of different origin (autologous, allogeneic or xenogeneic) and biodegradable materials (naturally occurring or synthetic polymers) as scaffolds for cell attachment and facilitated handling. For skin tissue engineering, the challenge that remains is the generation of a complex dermis-epidermal substitute that can be securely and conveniently transplanted with minimal scarring in one single surgical intervention ${ }^{2}$.

The success of tissue engineering is based on the ability of cells to adhere to an extracellular material and proliferate. This ability mainly depends on the interactions between the cells and the material surface. Thus, an ideal scaffold for tissue engineering should demonstrate considerable mechanical properties, suitable biodegradability and, most importantly, good biocompatibility33.

*e-mail: mgabriela@unifal-mg.edu.br
Furthermore, according to Malagutti \& $\mathrm{Kakhiara}^{4}$, an ideal dressing should present some features, such as: cost and accessibility, capacity of absorption, protection against contamination, maintenance of humid environment, exchange rate, ability to relieve pain, thermal isolation, odor filter, biodegradability, flexibility, transparency, among others.

Chitosan is a partially deacetylated derivative of chitin, which is the second more abundant polysaccharide found in nature and the primary structural polymer in arthropod exoskeletons ${ }^{5}$. Chitosan has generated enormous interest as a biomaterial due to its various advantages, such as (1) low cost, (2) easy availability, (3) biocompatibility and (4) anti-microbial activity ${ }^{6}$. The potential of chitosan as a tissue-engineering scaffold is based on its cationic nature and high charge density in solution. Due to its cationic nature, chitosan is allowed for electrostatic interactions with anionic glycosaminoglycans and proteoglycans ${ }^{7}$. These ionic interactions may serve as a mechanism for retaining and recruiting cells, growth factors, and cytokines within the tissue scaffold.

Chitosan exhibits others interesting biological activities, such as anti-tumor, immune-adjuvant, and hemostatic activities ${ }^{8}$. Moreover, it is metabolized by certain human enzymes, especially lysozyme, and is considered biodegradable? Due to its positive charges at physiological $\mathrm{pH}$, chitosan is bio-adhesive, which increases its retention on the site of application ${ }^{10}$. It can also accelerate wound healing ${ }^{11}$.

Due to all those properties, chitosan is one of the most important biomaterials for wound dressing management in the recent years. Chitosan is soluble in diluted acid solutions 
and can easily form films and membranes by casting. However, these films can be brittle and fragile, mainly after the neutralization process that removes residual acids from the films. Plasticizers, such as ethylene, polyethylene and propylene glycol and other polyols, has been used to improve physical and mechanical properties of chitosan films ${ }^{12-14}$. In this study, we used D-sorbitol, a biocompatible polyalcohol, as plasticizer to prepare a non-cytotoxic chitosan membrane with interesting properties for skin substitute and tissue engineering applications.

\section{Materials and Methods}

\subsection{Preparation of chitosan membranes}

Chitosan membranes were prepared by solvent evaporation technique. $1.0 \%(\mathrm{w} / \mathrm{w})$ Acetic Acid (Synth/Brazil) solution was used as solvent. $1.5 \mathrm{~g}$ of High Molecular Weight Chitosan (Sigma-Aldrich/USA) was dissolved in $100 \mathrm{ml}$ of solvent. Then, chitosan membrane (CA) was obtained by casting $20 \mathrm{ml}$ of chitosan solution in a Petri dish and drying at $40^{\circ} \mathrm{C}$. $0.2 \mathrm{~g}$ of D-sorbitol (Sigma-Aldrich/USA) was added to $20 \mathrm{ml}$ of the $1.5 \%$ chitosan solution under stirring for 1 hour. The resulted solution was casted in a Petri dish and dried at $40^{\circ} \mathrm{C}$ in order to prepare the plasticized membrane $(\mathrm{CP})$. The neutralized membrane $(\mathrm{CN})$ was prepared by immersing $\mathrm{CA}$ into $\mathrm{NaOH}(2 \% \mathrm{w} / \mathrm{w})-\mathrm{Na}_{2} \mathrm{Co}_{3}(0.05 \% \mathrm{w} / \mathrm{w})$ aqueous solution for 1 hour. Then, $\mathrm{CN}$ was repeatedly washed with distillated water and dried at $40^{\circ} \mathrm{C}$. Chitosan membranes $(\mathrm{CA}, \mathrm{CP}$ and $\mathrm{CN}$ ) were sterilized by ethylene oxide exposure for 8 hours at $40^{\circ} \mathrm{C}$, according to sterilization procedures.

\subsection{X-ray diffractometry (XRD)}

$\mathrm{X}$-ray diffraction was performed in a Powder Diffractometer $\mathrm{HZG} / 4 \mathrm{~A}$. The relative intensity was recorded in the scattering range (2 $\theta$ ) of 4 to $40^{\circ}$. Crystallinity index (Ic) of the samples was calculated according to Equation 1:

$\mathrm{Ic}=\left(\mathrm{I}_{0}-\mathrm{I}_{\mathrm{am}}\right) / \mathrm{I}_{0}$

Where $\mathrm{I}_{0}$ is the height of crystalline peak and $\mathrm{I}_{\mathrm{am}}$ is the amorphous scattering ${ }^{15}$.

\subsection{Scanning electron microscopy (SEM)}

SEM samples were coated with gold/palladium using a SC 7620 Sputter Coater - POLARON under high vacuum and $4 \mathrm{~mA}$ for 180 seconds. Coated samples were examined using a LEO 440i Scanning Electron Microscope.

\subsection{Water vapor permeability (WVP)}

WVP was measured according to ASTM E96-00 by the Desiccant method. Membranes were sealed to the open mouth of a test dish containing anhydrous calcium chloride, and the assembly was placed in a desiccator with controlled atmosphere $(75 \pm 2 \% \mathrm{RH})$. The dish assembly was daily weighted and the water vapor transmission rate was calculated ${ }^{16}$.

\subsection{Mechanical test}

The Electronic Digital Caliper (Fowler \& NSK - Max-Cal) was used to measure membranes thickness and TA-XT2 Instrument was used to measure tensile strength (TS) and elongation at break (E). Tests were carried out according to ASTM D882-12, with initial grip separation of $30 \mathrm{~mm}$ for $\mathrm{CA}$ and $\mathrm{CN}$ and $50 \mathrm{~mm}$ for CP. Cross head speed was fixed in $1 \mathrm{~mm} / \mathrm{s}$ in all tests ${ }^{17}$.

\subsection{Cell culture}

Vero cells, a cell line established from the kidney of the African green monkey (Cercopithecus aethiops), were obtained from Adolfo Lutz Institute, São Paulo, Brazil. These cells were cultured in Ham-F10 medium (Sigma-Aldrich/USA) supplemented with $10 \%$ fetal calf serum (FCS, Nutricell Nutrientes Celulares/Brazil) at $37^{\circ} \mathrm{C}$. Vero cells are recommended for studies of cytotoxicity and for cell-substratum interactions with biomaterials ${ }^{18-20}$. Cells were kept in culture flask of $25 \mathrm{~mL}$ or $50 \mathrm{~mL}$ before inoculation (Corning/USA) and medium was replaced periodically.

\subsection{MTT assay}

Vero cells were cultured on different chitosan membranes (CA, CP, and $\mathrm{CN}$ ) for a period of 24 hours. Six repetitions were made of all experiments. Test was carried out according to Mosmam's Methodology ${ }^{21}$. Briefly, the substrates were incubated in 96 well plates (Corning/USA) with cultured medium without FCS for $24 \mathrm{~h}$ at $37^{\circ} \mathrm{C}$. After this time, $100 \mu \mathrm{L}$ of cell suspension $\left(2.5 \times 10^{5}\right.$ cells $\left./ \mathrm{mL}\right)$ in Ham F-10 with $10 \%$ of FCS were added to the wells containing different chitosan samples. The wells were washed twice with $0.1 \mathrm{M}$ phosphate buffered saline (PBS) $\mathrm{pH} 7.4$, at $37^{\circ} \mathrm{C}$ and incubated with $100 \mu \mathrm{L}$ of Ham F-10 medium. The assay mixture $(10 \mu \mathrm{L}$ per well) containing $5 \mathrm{mg} / \mathrm{mL}$ of 3-(4,5-dimetiltiazol-2-il)-2,5 diphenyl tetrazolium bromide (MTT, Sigma-Aldrich/USA) was added to each well and incubated for $4 \mathrm{~h}$ at $37^{\circ} \mathrm{C}$. After $4 \mathrm{~h}, 100 \mu \mathrm{L}$ of isopropanol acid (Isofar Ind/Brazil) was added to each well and 3 hours later, cells were quantified by spectrophotometry, based on absorbance at $540 \mathrm{~nm}$ by using a Biorad Model 550 microplate reader Spectrophotometer (Hercules/USA). According to the ISO 10993-5, cells on poly-propylene culture plate by themselves were used as positive control, while culture medium with phenol $(2 \%)$ was used as negative toxicity control ${ }^{18}$. Absorbance of all experimental conditions (chitosan samples, negative or positive controls) without cells were also read for MTT reaction control. Comparison of continuous variables for all groups was done with ANOVA. When a significant difference was found, Turkey's HSD multiple comparison test was performed $(\mathrm{p}<0.05)$.

\subsection{Scanning electron microscopy analysis on cultured cells}

For cell morphology analysis by scanning electron microscopy (SEM), $2.5 \times 10^{5}$ cells $/ \mathrm{mL}$ were inoculated on different chitosan membranes (CA, CP and CN) in 24 wells culture plate (Corning/USA) feed with Ham F-10 medium with $10 \%$ FCS. Cells cultured on a glass coverslip, in the same culture conditions, were used as a control. After 48h, samples were fixed in 3\% glutaraldehyde (Sigma-Aldrich/USA) in $0.1 \mathrm{M}$ phosphate buffer at $\mathrm{pH} 7.2$ for 45 minutes at $4^{\circ} \mathrm{C}$, and post fixed with $1 \% \mathrm{OsO}_{4}$ (Sigma-Aldrich/USA) for $2 \mathrm{~h}$ at $4^{\circ} \mathrm{C}$. The specimens were then dehydrated in graded series of ethanol, critical point dried (Balzers CDT 030) and coated with gold in a sputter coater (Balzers CDT 050). Coated 
specimens were observed and photographed with a JEOL JSM-5800 scanning electron microscope.

\subsection{Light microscopy analysis}

For cell morphology analysis by light microscopy (LM), $2.5 \times 10^{5}$ cells $/ \mathrm{mL}$ were inoculated in a 24 wells culture plate (Corning) containing a chitosan sample (CA, $\mathrm{CP}$ or $\mathrm{CN})$ or one of the controls (positive or negative). Cells were feed with Ham F-10 medium with 10\% FCS. Alive cells were observed and photographed in inverted microscope IX-50 (Olympus, Hatagaya, Tokyo, Japan) after 48h, 120h and $240 \mathrm{~h}$ of cultured. In all experiments $n=5$.

\section{Results and Discussion}

\subsection{XRD and SEM}

According to Table 1, CN showed the highest index of crystallinity. The Index of crystallinity (Ic) may be used to compare the content of crystalline fraction of a number of samples. It differs from the degree of crystallinity that indicates the percentage of the crystalline fraction in the polymer ${ }^{15}$. Thus, Ic indicated that $\mathrm{CN}$ is more crystalline than CA and CP. Neutralization process promoted a molecular rearrangement in $\mathrm{CN}$ by removing the residual acetic acids molecules. This treatment also decreased the free volume around the polymer chains and increased their organization by crystallization. It also can be observed in Figure 1 that $\mathrm{CN}$ showed the chitosan's characteristic diffraction peaks at $10.5^{\circ}$ and $20.5^{\circ}$, as reported by Liu et al..$^{22}$. On the other hand, theses peaks were displaced to right for CA (peaks at $2 \theta=12^{\circ}$ and $2 \theta=22^{\circ}$ ) and they showed similar intensity, reducing the Ic. The presence of positive charges and contra-ions in CA inhibits organization of the polymer chains and hence decreases crystallinity. As expected after plasticizer addition, no distinct peak was observed for CP in Figure 1 that showed an amorphous pattern.

Although X-ray analysis showed considerable differences for $\mathrm{CA}, \mathrm{CN}$ and $\mathrm{CP}$, no significant morphological changes among samples were observed by SEM analysis (Figure 2). Liu et al. ${ }^{22}$ reported that the surface of sorbitol-spiked chitosan film was homogenous, continuous and smooth and stated that sorbitol offers good miscibility and compatibility when incorporated into chitosan, since no porous or discontinuities were found in plasticized film. We found similar results for all samples, which formed dense and package membranes. Nevertheless, CN showed some superficial rugosity, which can be attributed to neutralization treatment.

\subsection{WVP and mechanical tests}

WVP results are presented on Table 1. Plasticizers are theorized to decrease the intermolecular forces along polymer chains, increasing flexibility while decreasing the barrier properties of films. D-sorbitol is a hydrophilic molecule that contains six hydroxyl groups. It is a relatively small molecule that can be inserted between adjacent polymeric chains, decreasing intermolecular attractions. Thus, as expected, D-sorbitol addition increased WVP by increasing the free volume and enabling water vapor molecules to diffuse easily through the polymer chains. Ziani et al. ${ }^{14}$ also reported significant increase on WVP of chitosan films plasticized with glycerol.

According to mechanical properties, $\mathrm{CN}$ showed the highest tensile strength and the lowest elongation at break. This mechanical behavior can be attributed to the crystallinity of this sample after the neutralization process. On the other hand, CP showed the lowest tensile strength and the highest elongation at break (about 10 times higher when compared to $\mathrm{CN}$ ). For all plasticization systems, it is expected an increase in strain and a decrease in stress with increasing plasticizer amount. Suyatma et al. ${ }^{12}$ reported elongation at break of $7.2 \%, 84.6 \%, 19.1 \%$ and tensile strength of 63.1 $\mathrm{MPa}, 22.0 \mathrm{MPa}, 59.1 \mathrm{MPa}$ for chitosan film, 60/40 chitosan/glycerol and 95/5 plasticized films, respectively ${ }^{12}$. We found similar result of elongation at break $(83.12 \%)$ for $60 / 40$ chitosan/sorbitol membrane (CP). Besides, CA membrane mechanical properties $(18.8 \%$ and $58.62 \mathrm{MPa})$ are analogous to that found for $95 / 5$ chitosan/glycerol film. It confirms the hypothesis that positive charges and contra-ions in CA can act as plasticizer, and hence decrease tensile strength, besides increase elongation at break. $\mathrm{CN}$ showed mechanical properties compatible to that found for chitosan film by Suyatma et al. ${ }^{12}$.

Although tensile strength had been decreased by plasticizer addition, it still can be considerate for wound dressing, since average tensile strength of normal skin is $21.6 \pm 8.4 \mathrm{MPa}$ and the tensile strength of wounds used to be lower than the normal skin one, varying during the wound healing process ${ }^{23}$.

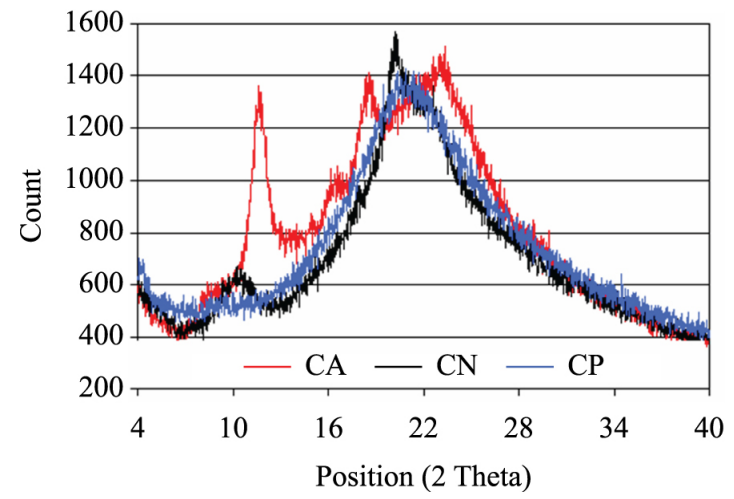

Figure 1. X-Ray diffractogram of membranes (CA - red, CN - black, $\mathrm{CP}-$ blue).

Table 1. Proprieties of chitosan membranes: thickness, water vapor permeability (WVP), crystallinity index (Ic), tensile strength (TS) and elongation at break (E).

\begin{tabular}{|c|c|c|c|c|c|}
\hline Sample & $\begin{array}{c}\text { Thickness } \\
\text { (mm) }\end{array}$ & 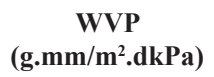 & $\begin{array}{c}\text { Ic } \\
(\%)\end{array}$ & $\begin{array}{c}\text { TS } \\
(\mathrm{MPa})\end{array}$ & $\begin{array}{c}\mathrm{E} \\
(\%)\end{array}$ \\
\hline $\mathrm{CA}$ & $0.0436 \pm 0.0028$ & $5.07 \pm 0.32$ & 14.6 & $58.62 \pm 1.87$ & $18.85 \pm 2.43$ \\
\hline $\mathrm{CN}$ & $0.0704 \pm 0.0043$ & $5.74 \pm 0.05$ & 56.7 & $79.83 \pm 4.49$ & $8.30 \pm 2.14$ \\
\hline $\mathrm{CP}$ & $0.0718 \pm 0.0089$ & $6.67 \pm 0.60$ & -- & $14.70 \pm 0.15$ & $83.12 \pm 1.66$ \\
\hline
\end{tabular}



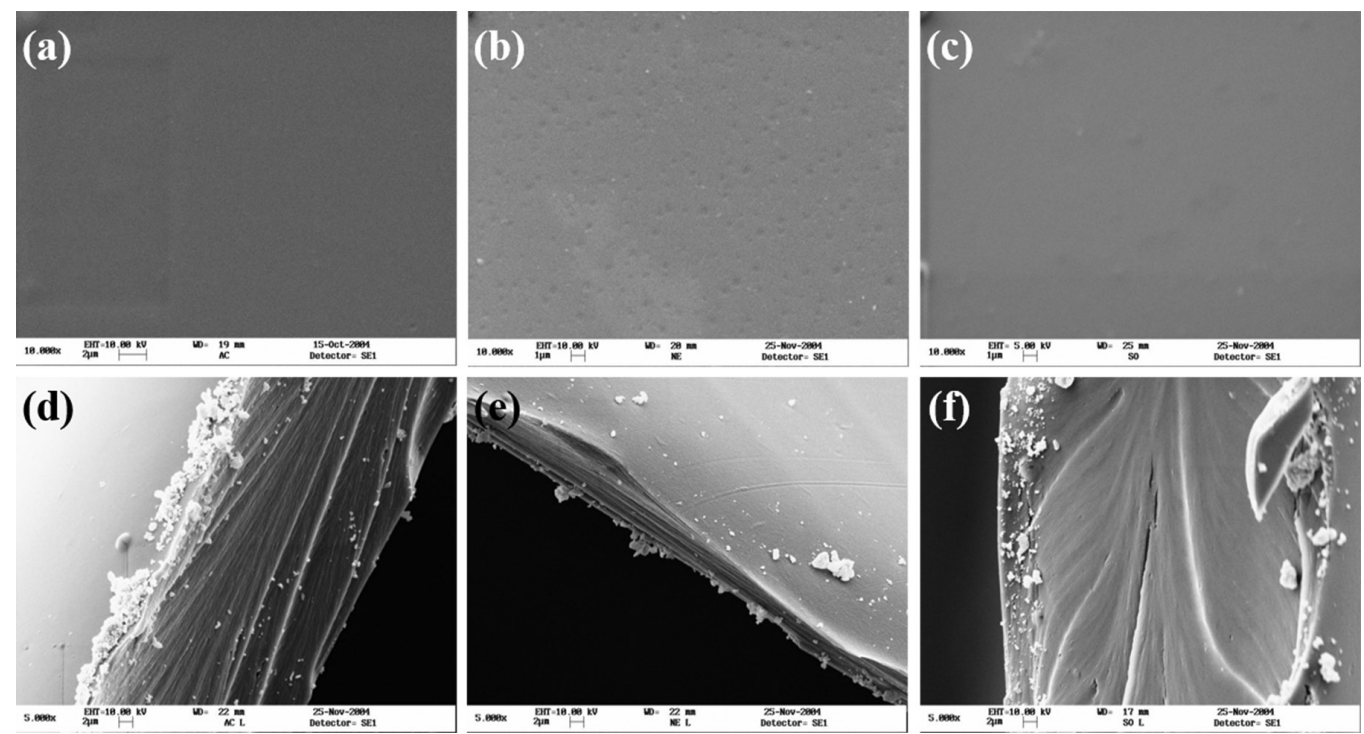

Figure 2. Micrographs of membranes. (a) Surface of chitosan membrane (CA); (b) Surface of chitosan neutralized membrane (CN); (c) Surface of sorbitol-chitosan plasticized membrane (CP); (d) Section of chitosan membrane (CA); (e) Section of chitosan neutralized membrane $(\mathrm{CN})$; (f) Section of sorbitol-chitosan plasticized membrane (CP).

\subsection{MTT assay}

Direct cytotoxicity test consisted of assessing possible toxic effects of chitosan membranes on direct contact to cells, while indirect cytotoxicity test evaluates the potential deleterious effects of substances released in the culture medium by chitosan membranes. Indirect cytotoxicity results (Figure 3) indicated that $\mathrm{CA}, \mathrm{CN}$ and $\mathrm{CP}$ did not release toxic substances to the culture media. Chitosan membranes (CA, $\mathrm{CN}$ and $\mathrm{CP}$ ) showed viable cell number higher than negative control one, what can be attributed to chitosan's biological property of stimulates cell proliferation. On the other hand, for direct toxicity evaluation, a possible toxic effect of CA was observed (Figure 4).

\subsection{Cell morphology by scanning electron microscopy}

By SEM, we found on CA retracted cell around cell fragments. In some regions, we could observe spreading cells or rounded cells near to cell fragments (Figures 5a). These fragments could be signals of cell degeneration. For $\mathrm{CN}$ we observed spreading cells with large processes linking them. Many vesicles and/or microvillus were also being found on cell surface. Apparently the vesicles and or microvillus were increased in comparison to others chitosan membranes (Figures $5 b$ ). On CP, we could observe spreading cell on substrate. In some regions, we found cell connected by thin processes. Some microvilli and/or vesicles could also be seen on cell surface (Figures $5 \mathrm{c}$ ).

\subsection{Cell morphology by light microscopy}

For negative control (culture plate), spreading cells growing on all times of incubation studied were found. After 48h, we could observe a confluent cells monolayer on the culture plates. Until $120 \mathrm{~h}$ of culture, we still could see spreading monolayer cells. Round cells that indicate cell division could also be seen in these times of incubation. Past 240h,

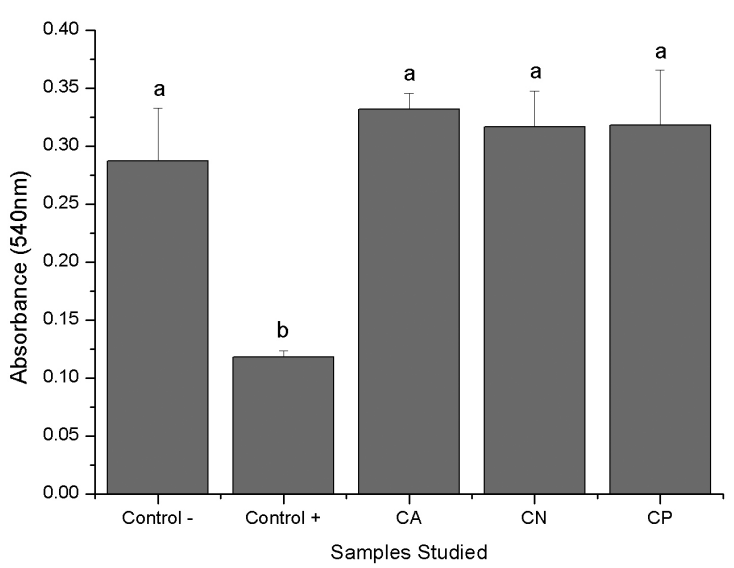

Figure 3. Indirect cytotoxicity test for chitosan substrates. We do not found any indirect toxic effect of CA, CP or CN. Different letters indicate significantly different means $(p<0.05)$.

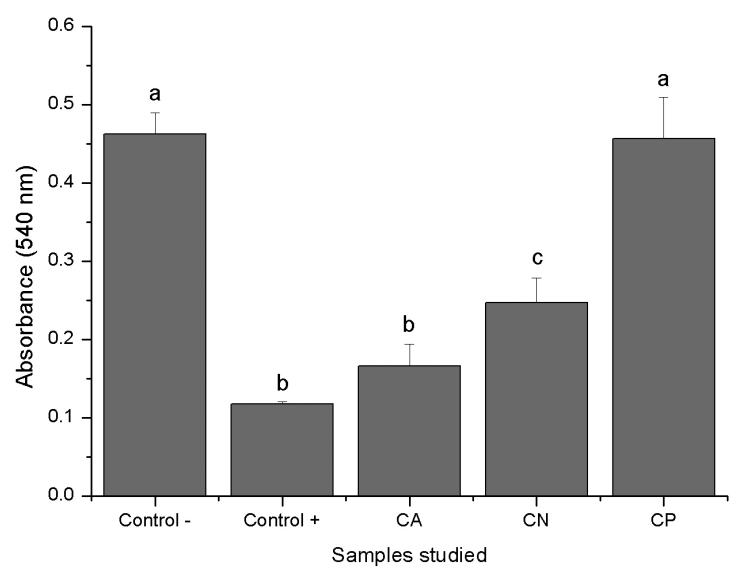

Figure 4. Direct cytotoxicity test for chitosan substrates. Our results indicated direct toxicity of CA membrane. Different letters indicate significantly different means $(p<0.05)$. 


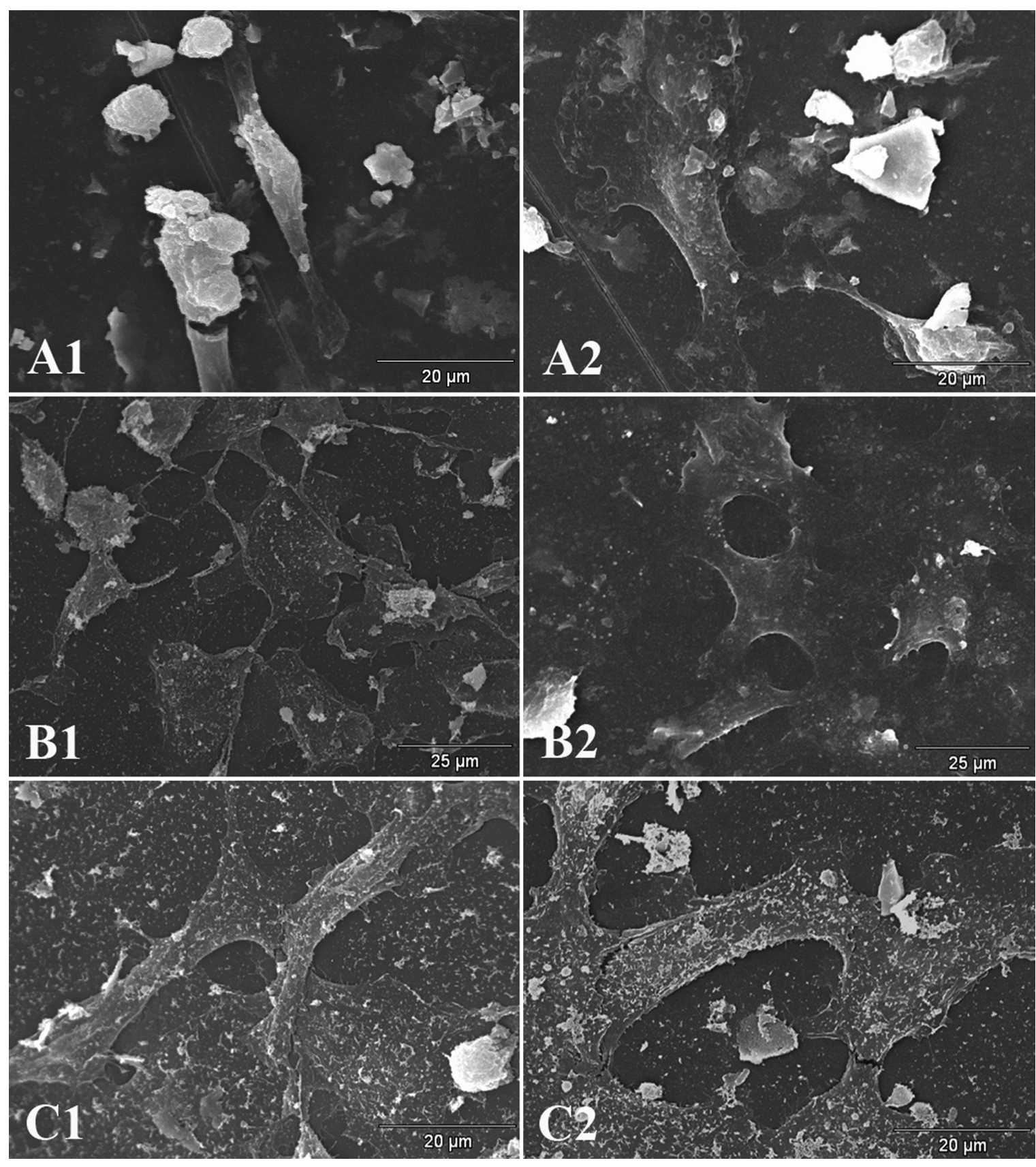

Figure 5. Morphology of Vero cells cultured on different chitosan membranes, obtained by scanning electron microscopy. (a) Chitosan membrane (CA); (b) Chitosan neutralized membranes (CN); (c) Chitosan plasticized membranes (CP).

rounded cells on the substrate were found, indicating loss of viability. Besides, numerous cells were observed flouting on the culture medium (Figures 6a). For positive control of toxicity (phenol), round and no viable cells on the substrate were observed for all incubation times. The cells number in all periods was, apparently, the same one, indicating no cell proliferation on that samples (Figures 6b).

For CA sample, round and aggregated cells on the substrate were found in the first $48 \mathrm{hs}$. However, cells aggregation was observed in small number. After $120 \mathrm{~h}$ of incubation, more spreading cells could be observed in the cellular aggregates. These cells were apparently trying to migrate for other regions of CA. Past 240h, a no confluent cell layer on CA was observed (Figure 6c). These pattern was different from non-toxic control and others chitosan membranes.

On the other hand, a similar cell behavior was observed for $\mathrm{CP}$ and $\mathrm{CN}$ samples. However, in the first $48 \mathrm{~h}$, we observed a no confluent spreading cell monolayer on $\mathrm{CP}$ and $\mathrm{CN}$ samples. After $120 \mathrm{~h}$, a confluent cell layer could be observed. Moreover, past 240h of incubation, multi-layers of cells on $\mathrm{CN}$ and $\mathrm{CP}$ samples were found (Figures $6 \mathrm{~d}$ and $6 \mathrm{e}$, respectively). Signals of cell degeneration were not evident.

In skin tissue engineering, generating scaffolds with mechanically strong properties and with flexible nature is 

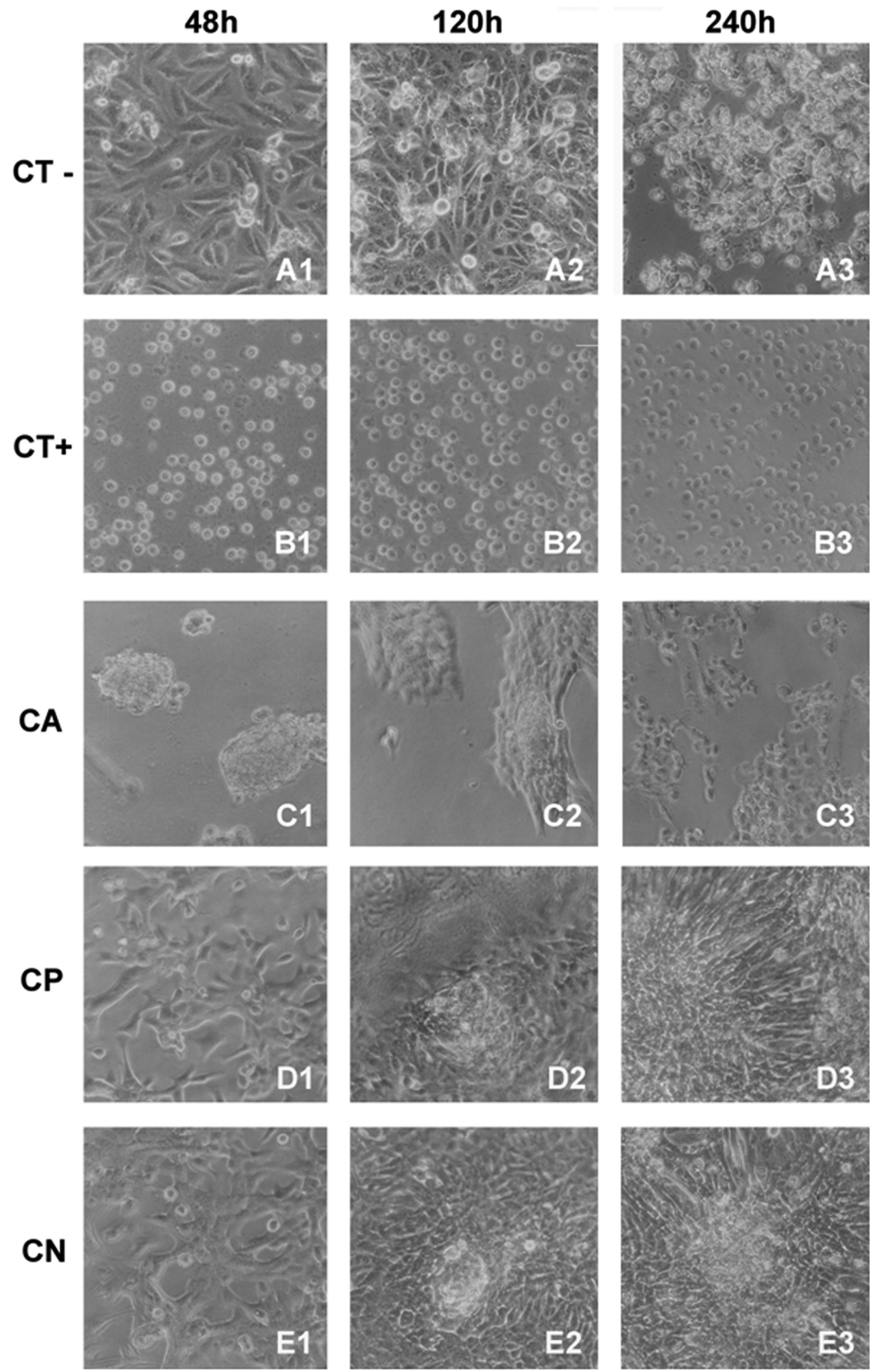

Figure 6. Morphology of Vero cells cultured on different chitosan membranes, obtained by light microscopy. (a) Negative control for cytotoxicity (CT-); (b) Positive control for cytotoxicity (CT+); (c) Chitosan membrane (CA); (c) Chitosan neutralized membrane (CN); (e) Sorbitol-chitosan plasticized membranes (CP). All assays were performed for 48, 120 and 240hs of cultured. 
required for regeneration epithelial and soft tissues. Based on these properties, chitosan scaffolds have been widely studied in epithelial and soft tissue engineering ${ }^{24}$. Chitosan scaffolds show both cytocompatibility in vitro and biocompatibility in vivo ${ }^{25}$. In our conditions, there was the need to test the possibility of toxicity of plasticizer used. The indirect cytotoxicity indicated that there was not liberation of toxic substances from the different chitosan samples to the culture medium. Surprisingly, in direct contact, the MTT assay showed a minor quantity of viable adherent cells on CA substrate. This result was confirmed by the morphological pattern of Vero cells cultured on CA. Rounded and aggregated cells in small areas of CA were observed. Maybe this result could be explained by acidification of CA by sample preparations conditions. After initial contact, some cells were capable to some proliferation to from cellular aggregates to CA surface. However, for $\mathrm{CP}$ and $\mathrm{CN}$, we found similar quantity of adherent viable cells on these substrates than culture plate, so were considered satisfactory as cell growth substrate. Thus, we conclude that neutralization is an important step in preparation of chitosan membranes since it removes residual acetic acid, which was found to be toxic for cells. Moreover, on basis of our cytotoxicity results, D-sorbitol can be considered a non-cytotoxic plasticizer.

Cell adhesion is a critical step in tissues engineering. For some cells of specific tissue types, sometimes, chitosan based biomaterials do not provide a good interface for cell interaction ${ }^{26,27}$. Therefore, other biomaterials, such as collagen $^{28,29}$, gelatin ${ }^{24}$, hyaluronan ${ }^{30}$, heparin ${ }^{31}$, silk fibroin ${ }^{32}$, fibrin $^{33}$ or poly-D-lysine ${ }^{34}$ with tissue-specific binding sequence, could be blended with chitosan to improve cell affinity. For this finality, and improve cell and tissue response, chitosan scaffolds also had been also loaded with many bioactive molecules, such as FGF2, EGF, PDGF, VEFG, IFN- $\gamma$ or TGF- $\beta 1^{35}$.

Cell spreading and morphology on chitosan substrates still are an unclear event. Structurally, chitosan is a linear polysaccharide consisting of $\beta(1 \rightarrow 4)$ linked D-glucosamine residues with a variable number of randomly located $\mathrm{N}$-acetyl-glucosamine groups. The average molecular weight ranges from 50 to $1.000 \mathrm{kDa}^{5}$. Chitosan had not a specific binding domain for cell adhesion mediated by integrin receptors. Also, no intracellular signaling pathway activated by chitosan contact is known ${ }^{36}$. Cells generally attach to an artificial culture substrate by binding to specific anchoring proteins that become adsorbed to the substrate surface. Chitosan acts as a positively charged center in solution, and the outside of the cell membrane carries negative charges. Based on the cationic nature of the chitosan polymer, an ionic complex can be formed between chitosan and specific bioactive compounds. This interaction leads to the spontaneous formation of polyelectrolyte complexes by establishing strong, but reversible links. The temporary polyelectrolyte complex networks formed without covalent cross-linkers are more biocompatible, sensitive, and easily controlled ${ }^{35}$. We found spreading cells on $\mathrm{CP}$ and $\mathrm{CN}$ surface. On $\mathrm{CN}$, we could see cell with a great quantities of microvillus and/or vesicles, indicating that this is the better surface for Vero cell growth.

For Ding et al. ${ }^{37}$, the electronic interaction between cell and substrate surface could modulate the cytoskeleton and cell morphology. Furthermore, Huang et al. ${ }^{38}$ suggest that cell spreading and morphology could be modulated by the structural characteristics of chitosan scaffolds. In that work, authors seeded cells on bi-dimensional (2D) and three-dimensional (3D) chitosan substrates. In 2-D condition, cells were restricted to spread on a flat plane and the important factor affecting cellular activity was whether the substrate contains or no cell adhesion binding domains. In contrast, 3-D matrices provided spatial advantages for cell-cell and cell-matrix adhesion as well as support for cell traction ${ }^{38}$. This is a behavior similar than fibroblast in $2 \mathrm{D}$ and $3 \mathrm{D}$ collagen substrates, classically reported ${ }^{39,40}$.

We found cell adhesion images, with cell aggregates, similar as previously described ${ }^{26}$. Lin et al., hypothesized a balance between two competing forces among the interactions of cell-substrate and cell-cell. For this authors, when in a low cell density were seeded on the surface of chitosan, dominance of cell-substrate interaction results in cell attachment since the distance between cells is so large to cause relatively small cell-cell interaction ${ }^{26}$. On the other hand, when the distance between cells decreases at high seeding density, the inhibition of cell migration by the chitosan is overcome by the enhanced cell-cell interaction, which allows cell aggregation and subsequent formation of spheroid. The reduction in cell size was thought to be also result of strong electrostatic interactions associated with deacetylation degree ${ }^{41}$. Changes on cellular activity induced by different deacetylation degrees could not be significantly relative to other adhesive forces. ${ }^{38}$ Nevertheless, cells proliferation inhibition found on chitosan scaffolds could be due to reduced adhesion and not to strong adhesion ${ }^{41}$.

The results of our in vitro study suggest that $\mathrm{CP}$ and $\mathrm{CN}$ can support the initial attachment and spreading of Vero cells. These findings are in accordance to previous reports that showed similar morphological pattern of cells cultured on chitosan surfaces. Microscopic observations at $1 \mathrm{~h}$ revealed that osteoblasts were attached and beginning to spread. In contrast, fibroblasts showed rounded morphologies with markedly reduced attachment levels ${ }^{42}$. Previous reports have shown conflicting results about the effects of chitosan on fibroblasts. While chitosan has been shown to have stimulatory effect on fibroblast activity ${ }^{25,43}$, other results have shown some inhibitory effects of chitosan on fibroblasts growth ${ }^{44,45}$. Maybe, sample preparation or different culture conditions could explain these discrepant results.

Classically, Mori et al. ${ }^{44}$ examined the effects of chitin and its derivatives on fibroblasts proliferation. Their results indicated that chitosan has no effect on in vitro fibroblasts proliferation. However, other reports showed that chitosan could indirectly accelerate fibroblast proliferation in vivo ${ }^{46}$. In other reports that chitosan immobilization on PLGA surface have been studied, it was not observed effects of chitosan on cell proliferation ${ }^{37}$. Finally, it was shown that chitosan could accelerate the production of biological mediators. In relation to fibroblast proliferation, it was suggested that chitosan could act as stimulator or repressor with variation of different concentration levels ${ }^{47}$. Our results suggested no effect on cell proliferation, since the same number of cells for chitosan substrates ( $\mathrm{CP}$ and $\mathrm{CN}$ ) were counted when compared to the negative control (culture plate). 
Mei et al. ${ }^{48}$ showed the cell morphology on polycaprolactone (PCL) and chitosan-modified scaffolds. It was reported that chitosan modification dramatically enhances cellular affinity and compatibility for PCL scaffolds. Cells were more firmly adhered on chitosan-modified PCL and more elongated and stretched on this substrate. Moreover, cell adhesion and proliferation on PCL scaffolds were considerably improved after chitosan modification ${ }^{48}$. On the other hand, other forms of PCL-Chitosan blends showed no alteration on growth and proliferation pattern on blends in relation to pure polymers ${ }^{49}$. Conflicting results among published data on chitosan-mediate fibroblast cells attachment may be explained by differences in cell population analyzed and by variation in properties of tested chitosan ${ }^{42}$.

After $240 \mathrm{hs}$ of incubation on chitosan samples, morphological analysis showed cells growing such as many layers. That growth pattern indicates a satisfactory proliferation of cells on those chitosan substrates. It also indicates that $\mathrm{CP}$ and $\mathrm{CN}$ can support cellular growth after normal decrease of viability, as well observed in negative control for the same period of incubation. We suggest that hydrophilic character of D-sorbitol that contains six hydroxyl groups in its molecule can contribute for cell proliferation on the plasticized membrane, $\mathrm{CP}$. For $\mathrm{CN}$, the protonated amino group besides residual acetic acid removal by neutralization may serve as a mechanism for retaining cells due to the electrostatic interactions with glycosaminoglycan and proteoglycans ${ }^{7}$. In addition, our morphologic observations showed a reduction of cell spreading in chitosan substrates when compared to culture plate (negative control). Similar trend was previously reported by Sarasam \& Madihally ${ }^{6}$ who observed a drastic decrease in the cell spreading area from control to chitosan.

\section{References}

1. Zavan B, Vindigni V, Cortivo R and Abatangelo G. Skin substitutes. In: Eberli D, editor. Tissue Engineering. Olajnica: In-Tech; 2010. p. 509-524.

2. Böttcher-Haberzeth S, Biedermann T and Reichmann E. Tissue engineering of skin. Burns. 2010; 36(4):450-460. http://dx.doi. org/10.1016/j.burns.2009.08.016. PMid:20022702.

3. Santos AR Jr, Lombello CB and Genari SC. Technologies applied to stimulate bone regeneration. In: Davies J, editor. Tissue regeneration - from basic biology to clinical application. 1st ed. Rijeka: InTech; 2012. p. 339-366.

4. Malagutti W and Kakihara CT. Curativos, estomias e dermatologia: uma abordagem multiprofissinal. São Paulo: Martinari; 2010; $544 \mathrm{p}$.

5. Yamane S, Iwasaki N, Majima T, Funakoshi T, Masuko T, Harada $\mathrm{K}$, et al. Feasibility of chitosan-based hyaluronic acid hybrid biomaterial for a novel scaffold in cartilage tissue engineering. Biomaterials. 2005; 26(6):611-619. http://dx.doi.org/10.1016/j. biomaterials.2004.03.013. PMid:15282139.

6. Sarasam A and Madihally SV. Characterization of chitosanpolycaprolactone blends for tissue engineering applications. Biomaterials. 2005; 26(27):5500-5508. http://dx.doi.org/10.1016/j. biomaterials.2005.01.071. PMid:15860206.

7. Madihally SV and Matthew HW. Porous chitosan scaffolds for tissue engineering. Biomaterials. 1999; 20(12):1133-1142. http:// dx.doi.org/10.1016/S0142-9612(99)00011-3. PMid:10382829.
Uygun et al. ${ }^{50}$ studied the influence of chitosan membrane structure on the behavior of cells. The authors observed increased cells spreading on the substrate with increasing membrane thickness. Moreover, they reported the positive effect of an increased amorphous fraction in membranes on cell spreading and proliferation ${ }^{50}$. This result indicates that the use of sorbitol in order to reduce crystallinity of chitosan membrane (Figure 1) is an alternative way to enhance cell spreading and proliferation on the substrate. Therefore, $\mathrm{CP}$ formulation can be further manipulated to achieve enhanced cell spreading and proliferation.

\section{Conclusions}

We presented a study on sorbitol-plasticized and neutralized chitosan membranes for skin substitution. Both membranes showed to be non-cytotoxic as well as good surface for cell growth. D-sorbitol improved WVP and flexibility of chitosan membranes by reducing crystallinity. Because of the enhancement of cell spreading and proliferation on amorphous substrates, D-sorbitol concentration can be further modified to achieve desirable properties for skin tissue-engineering applications.

\section{Acknowledgements}

This research was supported by $\mathrm{CNPq}$ - Conselho Nacional de Desenvolvimento Científico e Tecnológico, CAPES - Coordenação de Aperfeiçoamento de Pessoal de Nível Superior and FAPESP - Fundação de Amparo à Pesquisa do Estado de São Paulo.

8. Kurita K. Chemistry and application of chitin and chitosan. Polymer Degradation \& Stability. 1998; 59(1-3):117-120. http://dx.doi.org/10.1016/S0141-3910(97)00160-2.

9. Muzzarelli RAA. Human enzymatic activities related to the therapeutic administration of chitin derivatives. Cellular and Molecular Life Sciences : CMLS. 1997; 53(2):131-140. http:// dx.doi.org/10.1007/PL00000584. PMid:9118001.

10. Berger J, Reist M, Mayer JM, Felt O, Peppas NA and Gurny R. Structure and interactions in covalently and ionically crosslinked chitosan hydrogels for biomedical applications. European Journal of Pharmaceutics and Biopharmaceutics. 2004; 57(1):19-34. http://dx.doi.org/10.1016/S0939-6411(03)00161-9. PMid:14729078.

11. Synowiecki J and Al-Khateeb NA. Production, properties, and some new applications of chitin and its derivatives. Critical Reviews in Food Science and Nutrition. 2003; 43(2):145-171. http://dx.doi.org/10.1080/10408690390826473. PMid:12705640.

12. Suyatma NE, Tighzert L, Copinet A and Coma V. Effects of hydrophilic plasticizers on mechanical, thermal, and surface properties of chitosan films. Journal of Agricultural and Food Chemistry. 2005; 53(10):3950-3957. http://dx.doi.org/10.1021/ jf048790+. PMid:15884822.

13. Arvanitoyannis IS, Nakayamab A and Aiba S. Chitosan and gelatin based edible films: state diagrams, mechanical and permeation properties. Carbohydrate Polymers. 1998; 37(4):371382. http://dx.doi.org/10.1016/S0144-8617(98)00083-6. 
14. Ziani K, Oses J, Coma V and Maté JI. Effect of the presence of glycerol and Tween 20 on the chemical and physical properties of films based on chitosan with different degree of deacetylation. LWT - Food Science and Technology. 2008; 41(10):2159-2165. http://dx.doi.org/10.1016/j.lwt.2007.11.023.

15. Ieolovich M. Crystallinity and hydrophility of chitin and chitosan. Research and Reviews: Journal of Chemistry. 2014; 3(3):7-14.

16. American Society for Testing and Materials - ASTM. ASTM E96: Standard Test methods for water vapor transmission of materials. West Conshohocken: ASTM; 2000.

17. American Society for Testing and Materials - ASTM. ASTM D882: Standard test method for tensile properties of thin plastic sheeting. West Conshohocken: ASTM; 2012.

18. International Organization for Standardization - ISO. ISO 10993-1: International standard. Biological evaluation of medical devices - part 1 - evaluation and testing. Geneva: ISO; 1997.

19. International Organization for Standardization - ISO. ISO 10993-1: Biological evaluation of medical devices - part 5 tests for cytotoxicity: in vitro methods. Geneva: ISO; 2009.

20. Kirkpatrick CJ. Biological testing of materials and medical devices - a critical view of current and proposed methodologies for biocompatibility testing: cytotoxicity in vitro. Regul Affairs. 1992; 4:13-32.

21. Mosmann T. Rapid colorimetric assay for cellular growth and survival: application to proliferation and cytotoxicity assays. Journal of Immunological Methods. 1983; 65(1-2):55-63. http:// dx.doi.org/10.1016/0022-1759(83)90303-4. PMid:6606682.

22. Liu M, Zhou Y, Zhang Y, Yu C and Cao S. Preparation and structural analysis of chitosan films with and without sorbitol. Food Hydrocolloids. 2013; 33(2):186-191. http://dx.doi. org/10.1016/j.foodhyd.2013.03.003.

23. Ní Annaidh A, Bruyère K, Destrade $M$, Gilchrist MD and Otténio M. Characterization of the anisotropic mechanical properties of excised human skin. Journal of the Mechanical Behavior of Biomedical Materials. 2012; 5(1):139-148. http:// dx.doi.org/10.1016/j.jmbbm.2011.08.016. PMid:22100088.

24. Yang J, Woo SL, Yang G, Wang J, Cui L, Liu W, et al. Construction and clinical application of a human tissueengineered epidermal membrane. Plastic and Reconstructive Surgery. 2010; 125(3):901-909. http://dx.doi.org/10.1097/ PRS.0b013e3181cc9665. PMid:20009787.

25. Muzzarelli R, Baldassarre V, Conti F, Ferrara P, Biagini G, Gazzanelli G, et al. Biological activity of chitosan: ultrastructural study. Biomaterials. 1988; 9(3):247-252. http://dx.doi. org/10.1016/0142-9612(88)90092-0. PMid:3408796.

26. Lin SJ, Jee SH, Hsaio WC, Lee SJ and Young TH. Formation of melanocyte spheroids on the chitosan-coated surface. Biomaterials. 2005; 26(12):1413-1422. http://dx.doi.org/10.1016/j. biomaterials.2004.05.002. PMid:15482829.

27. Huang TW, Young YH, Cheng PW, Chan YH and Young TH. Culture of nasal epithelial cells using chitosan-based membranes. The Laryngoscope. 2009; 119(10):2066-2070. http://dx.doi. org/10.1002/lary.20609. PMid:19572267.

28. Shi H, Han C, Mao Z, Ma L and Gao C. Enhanced angiogenesis in porous collagen-chitosan scaffolds loaded with angiogenin. Tissue Engineering. Part A. 2008; 14(11):1775-1785. http:// dx.doi.org/10.1089/ten.tea.2007.0007. PMid:18950270.

29. Zhu C, Fan D, Duan Z, Xue W, Shang L, Chen F, et al. Initial investigation of novel human-like collagen/chitosan scaffold for vascular tissue engineering. Journal of Biomedical Materials
Research. Part A. 2009; 89(3):829-840. http://dx.doi.org/10.1002/ jbm.a.32256. PMid:19165794.

30. Funakoshi T, Majima T, Iwasaki N, Yamane S, Masuko T, Minami A, et al. Novel chitosan-based hyaluronan hybrid polymer fibers as a scaffold in ligament tissue engineering. Journal of Biomedical Materials Research. Part A. 2005; 74(3):338-346. http://dx.doi.org/10.1002/jbm.a.30237. PMid:16013058.

31. Chupa JM, Foster AM, Sumner SR, Madihally SV and Matthew HW. Vascular cell responses to polysaccharide materials: in vitro and in vivo evaluations. Biomaterials. 2000; 21(22):23152322. http://dx.doi.org/10.1016/S0142-9612(00)00158-7. PMid:11026638.

32. Gobin AS, Froude VE and Mathur AB. Structural and mechanical characteristics of silk fibroin and chitosan blend scaffolds for tissue regeneration. Journal of Biomedical Materials Research. Part A. 2005; 74(3):465-473. http://dx.doi.org/10.1002/ jbm.a.30382. PMid:15983992.

33. Han CM, Zhang LP, Sun JZ, Shi HF, Zhou J and Gao CY. Application of collagen-chitosan/fibrin glue asymmetric scaffolds in skin tissue engineering. Journal of Zhejiang University. Science. B. 2010; 11(7):524-530. http://dx.doi.org/10.1631/ jzus.B0900400. PMid:20593518.

34. Crompton KE, Goud JD, Bellamkonda RV, Gengenbach TR, Finkelstein DI, Horne MK, et al. Polylysine-functionalised thermoresponsive chitosan hydrogel for neural tissue engineering. Biomaterials. 2007; 28(3):441-449. http://dx.doi.org/10.1016/j. biomaterials.2006.08.044. PMid:16978692.

35. Yang TL. Chitin-based materials in tissue engineering: applications in soft tissue and epithelial organ. International Journal of Molecular Sciences. 2011; 12(3):1936-1963. http:// dx.doi.org/10.3390/ijms12031936. PMid:21673932.

36. Hynes RO and Zhao Q. The evolution of cell adhesion. The Journal of Cell Biology. 2000; 150(2):F89-F96. http://dx.doi. org/10.1083/jcb.150.2.F89. PMid:10908592.

37. Ding Z, Chen J, Gao S, Chang J, Zhang J and Kang ET. Immobilization of chitosan onto poly-L-lactic acid film surface by plasma graft polymerization to control the morphology of fibroblast and liver cells. Biomaterials. 2004; 25(6):10591067. http://dx.doi.org/10.1016/S0142-9612(03)00615-X. PMid:14615171.

38. Huang Y, Onyeri S, Siewe M, Moshfeghian A and Madihally $\mathrm{SV}$. In vitro characterization of chitosan-gelatin scaffolds for tissue engineering. Biomaterials. 2005; 26(36):7616-7627. http:// dx.doi.org/10.1016/j.biomaterials.2005.05.036. PMid:16005510.

39. Grinnell F, Rocha LB, Iucu C, Rhee S and Jiang H. Nested collagen matrices: a new model to study migration of human fibroblast populations in three dimensions. Experimental Cell Research. 2006; 312(1):86-94. PMid:16256985.

40. Rhee S. Fibroblasts in three dimensional matrices: cell migration and matrix remodeling. Experimental \& Molecular Medicine. 2009; 41(12):858-865. http://dx.doi.org/10.3858/ emm.2009.41.12.096. PMid:19745603.

41. Mao JS, Cui YL, Wang XH, Sun Y, Yin YJ, Zhao HM, et al. A preliminary study on chitosan and gelatin polyelectrolyte complex cytocompatibility by cell cycle and apoptosis analysis. Biomaterials. 2004; 25(18):3973-3981. http://dx.doi.org/10.1016/j. biomaterials.2003.10.080. PMid:15046887.

42. Fakhry A, Schneider GB, Zaharias R and Senel S. Chitosan supports the initial attachment and spreading of osteoblasts preferentially over fibroblasts. Biomaterials. 2004; 25(11):20752079. http://dx.doi.org/10.1016/j.biomaterials.2003.08.068. PMid:14741622.

43. Lahiji A, Sohrabi A, Hungerford DS and Frondoza CG. Chitosan supports the expression of extracellular matrix 
proteins in human osteoblasts and chondrocytes. Journal of Biomedical Materials Research. 2000; 51(4):586-595. http:// dx.doi.org/10.1002/1097-4636(20000915)51:4<586::AIDJBM6>3.0.CO;2-S. PMid:10880106.

44. Mori T, Okumura M, Matsuura M, Ueno K, Tokura S, Okamoto $\mathrm{Y}$, et al. Effects of chitin and its derivatives on the proliferation and cytokine production of fibroblasts in vitro. Biomaterials. 1997; 18(13):947-951. http://dx.doi.org/10.1016/S01429612(97)00017-3. PMid:9199765.

45. Berscht PC, Nies B, Liebendörfer A and Kreuter J. Incorporation of basic fibroblast growth factor into methylpyrrolidinone chitosan fleeces and determination of the in vitro release characteristics. Biomaterials. 1994; 15(8):593-600. http:// dx.doi.org/10.1016/0142-9612(94)90209-7. PMid:7948578.

46. Ueno H, Yamada H, Tanaka I, Kaba N, Matsuura M, Okumura $\mathrm{M}$, et al. Accelerating effects of chitosan for healing at early phase of experimental open wound in dogs. Biomaterials. 1999; 20(15):1407-1414. http://dx.doi.org/10.1016/S01429612(99)00046-0. PMid:10454012.
47. Ueno H, Mori T and Fujinaga T. Topical formulations and wound healing applications of chitosan. Advanced Drug Delivery Reviews. 2001; 52(2):105-115. http://dx.doi.org/10.1016/S0169409X(01)00189-2. PMid:11718934.

48. Mei N, Chen G, Zhou P, Chen X, Shao ZZ, Pan LF, et al. Biocompatibility of Poly(epsilon-caprolactone) scaffold modified by chitosan--the fibroblasts proliferation in vitro. Journal of Biomaterials Applications. 2005; 19(4):323-339. http://dx.doi. org/10.1177/0885328205048630. PMid:15788428.

49. Cardoso GBC, Machado-Silva AB, Sabino M, Santos AR Jr and Zavaglia CAC. Novel hybrid membrane of chitosan/ poly ( $\varepsilon$-caprolactone) for tissue engineering. Biomatter. 2014; 4(1):e29508. http://dx.doi.org/10.4161/biom.29508. PMid:25093398.

50. Uygun BE, Bou-Akl T, Albanna M and Matthew HW. Membrane thickness is an important variable in membrane scaffolds: Influence of chitosan membrane structure on the behavior of cells. Acta Biomaterialia. 2010; 6(6):2126-2131. http://dx.doi. org/10.1016/j.actbio.2009.11.018. PMid:19925888. 